\title{
Potwierdzanie kompetencji personelu badań nieniszczących według standardów światowych
}

\section{Confirmation of the competence of NDT personnel according to the world standards}

\section{Streszczenie}

Odpowiednie i odpowiednio potwierdzone kompetencje pracowników to dzisiaj główna troska i wymaganie każdego pracodawcy. Personel NDT stanowi szczególne ogniwo w łańcuchu działań zmierzających do najwyższej jakości i bezpieczeństwa eksploatacyjnego urządzeń technicznych.

Kompetencje personelu NDT na świecie potwierdzane są w oparciu o EN ISO 9712:2012. W artykule przedstawiono problematykę związaną z certyfikacją wg ww. normy, a w tym ogólny schemat certyfikacji. Określono przypadki, w których jest wymagana lub oczekiwana certyfikacja. Omówiono również kompetencje poszczególnych stopni kwalifikacji i ich odpowiedzialności w związku z zakresem możliwych upoważnień.

Odniesiono się do obowiązków i odpowiedzialności pracodawców osób certyfikowanych.

Wskazano na wymagania akredytacyjne dla personelu zatrudnionego w laboratorium badań nieniszczących.

Słowa kluczowe: personel NDT, kompetencje, certyfikacja

\section{Abstract}

Adequate and properly confirmed the competence of employees is a major concern and requirement of each employer nowadays. NDT personnel is a special link in the chain of actions aimed at the highest quality and operational safety of technical equipment. NDT personnel competences in the world are confirmed on the basis of EN ISO 9712: 2012.

The paper is managing to deal with all of the important problems connected with the certification by the above standards as well as the general scheme of certification. Required or expected certification fields and cases are discussed. It also presents the competence of various levels of qualifications and their responsibilities in the relation to the range of possible authorizations to operate. The duties and responsibilities of employers of certified persons was indicated.

The accreditation requirements for staff employed in non-destructive testing laboratory was pointed to.

Keywords: NDT personnel, competences, certification

\section{Wstęp}

Odpowiedni poziom kompetencji czyli zdolności stosowania wiedzy i umiejętności w celu osiągnięcia zamierzonych wyników, stanowi podstawowe wymaganie dla każdego pracownika. Pracodawcy chętniej zatrudniają osoby spełniające kryteria w danej dziedzinie, w szczególności zaś osoby, które posiadają odpowiednie dokumenty, wydane przez jednostkę niezależną, potwierdzające posiadane kompetencje. Obserwuje się coraz większe zainteresowanie certyfikacją osób w wielu obszarach, w tym w badaniach nieniszczących. Osoby wykonujące NDT stanowią szczególną grupę w łańcuchu działań dotyczących bezpieczeństwa urządzeń technicznych i ich jakości.

$\mathrm{Na}$ świecie istnieją dwa główne systemy potwierdzania kompetencji personelu NDT.

Pierwszym z nich jest międzynarodowy system certyfikacji prowadzony według EN ISO 9712, która w 2012 roku ustanowiona została normą "światową". Do tego czasu w Europie stosowano certyfikację wg systemu EN 473, zaś ISO 9712 dotyczyła głównie USA. Certyfikację taką prowadzą akredytowane jednostki certyfikujące spełniające wymagania PN-EN ISO/IEC 17024, które kompetencje personelu NDT potwierdzają pisemnie poprzez wydanie certyfikatu kompetencji. Są to certyfikaty akredytowane, gdyż wydane przez jednostkę akredytowaną [1].

Inny system to certyfikacja, a właściwie zatwierdzanie personelu NDT przez pracodawcę w oparciu o określone przez niego wymagania. Postępowanie pracodawcy może być również zgodne z wymaganiami EN ISO/IEC 17024.

W każdym przypadku potwierdzenie kompetencji w postaci pisemnego certyfikatu / zatwierdzenia następuje po procesie kwalifikowania czyli sprawdzenia i upewnienia się, w oparciu o dostarczone dowody w postaci np. zaświadczeń / świadectw, że osoba wnioskująca o certyfikację / zatwierdzenie spełniła wymagania dotyczące wykształcenia, szkolenia i doświadczenia.

Mgr inż. Marta Wojas - Urząd Dozoru Technicznego.

Autor korespondencyjny/Corresponding author. marta.wojas@udt.gov.pl 


\section{Podstawowe pojęcia \\ z zakresu kwalifıkowania i certyfikacji personelu NDT}

Pojęcia z zakresu kwalifikowania i certyfikacji personelu NDT definiują normy PN-EN ISO 9712 oraz PN-EN ISO/IEC 17024 [2], które zostały wdrożone do normalizacji polskiej i są identyczne z ww. normami. Są to:

- certyfikacja, która obejmuje: wnioskowanie, ocenę i decyzję w sprawie certyfikacji oraz ponowną certyfikację - procedura - za pomocą której jednostka certyfikująca ustala, czy dana osoba spełnia wymagania certyfikacyjne czyli wyspecyfikowane wymagania, które muszą być spełnione, aby uzyskać lub utrzymać certyfikację;

- kwalifikacja czyli udowodnione wykształcenie, szkolenie i doświadczenie zawodowe oraz predyspozycje fizyczne, jeśli wymagane, jako wymaganie wstępne;

- kompetencje to zdolność do stosowania wiedzy i umiejętności w celu osiągnięcia zamierzonego celu.

Powyższe pojęcia wskazują, że w procesie certyfikacji najpierw następuje kwalifikowanie czyli sprawdzenie, czy zostały spełnione wymagania wstępne, co odbywa się w oparciu o dokumenty potwierdzające spełnienie tych wymagań. Należą do nich: wniosek o certyfikację, w którym pracodawca przedstawia osobę wnioskującą jednostce certyfikującej. We wniosku określa się wykształcenie oraz ukończone odpowiednie kursy szkoleniowe, praktykę w metodzie, w której wnioskuje się o certyfikację oraz spełnienie wymagań dotyczących wzroku. Ukończenie odpowiedniego kursu szkoleniowego oraz wynik badania wzroku powinny być potwierdzone akceptowalnymi przez jednostkę dokumentami, np. uwierzytelnionymi kopiami odpowiednich świadectw. Kurs powinien być ukończony odpowiednio do wnioskowanych metody, stopnia i sektora, a wynik tego kursu powinien być pozytywny, co powinno być poświadczone na świadectwie ukończenia kursu. Kurs powinien być zatwierdzony przez jednostkę certyfikującą, w której złożono wniosek o certyfikację.

Praktyka powinna odbywać się pod kwalifikowanym nadzorem osoby posiadającej odpowiedni certyfikat (w metodzie i sektorze) lub przez osobę nie certyfikowaną, akceptowaną przez jednostkę. Praktyka powinna być potwierdzona przez taką osobę.

Spełnienie ww. wymagań upoważnia jednostkę certyfikującą do zakwalifikowania kandydata do egzaminu kwalifikacyjnego. Pozytywny wynik egzaminu oraz spełnienie wszystkich wymagań stanowi podstawę do podjęcia decyzji o certyfikacji i wydania pisemnego potwierdzenia - certyfikatu. Rysunek 1 przedstawia schemat procesu certyfikacji.

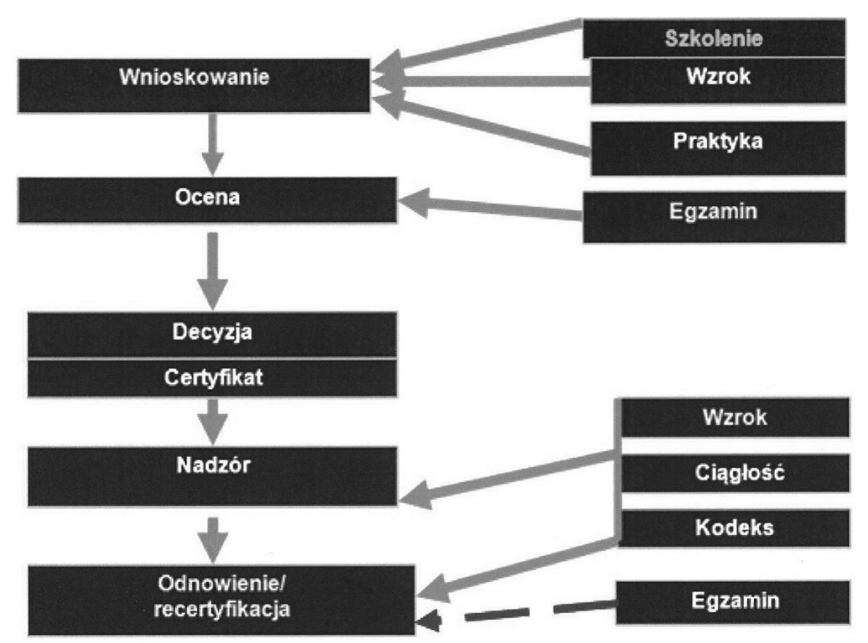

Rys. 1. Schemat certyfikacji personelu badań nieniszczących Fig. 1. NDT personnel certification scheme

\section{Kiedy potrzebna jest certfikacja?}

Certyfikacja może być dobrowolna, ale może być również odpowiedzią na wymagania przepisów prawa, normy czy na zapotrzebowanie rynku.

\section{Przepisy}

W UE istnieje przepis techniczny w postaci dyrektywy ciśnieniowej PED nr 97/23/WE [3] (2014/68/WE) ${ }^{2}$ [4], zawierający wymagania zasadnicze dotyczące urządzeń ciśnieniowych. Wśród tych wymagań, w załączniku I w pkt 3.1.3, znajdujemy wymaganie dotyczące personelu wykonującego badania nieniszczące połączeń nierozłącznych, które brzmi:

„Badania nieniszczące połączeń nierozłącznych ... przeprowadzane są przez odpowiednio wykwalifikowany personel. W przypadku urządzeń ciśnieniowych należących do kategorii IIl i IV personel musi zostać zatwierdzony przez organizację strony trzeciej uznaną przez dane państwo członkowskie zgodnie..." z art. 13 (wg 97/23/WE) lub art. 20 wg 2014/68/WE.

\section{Jak spełnić to wymaganie?}

Wg dyrektywy ciśnieniowej państwa członkowskie powinny uznać i notyfikować do KE i innych krajów członkowskich uznane jednostki trzeciej strony (Recognised Third Party Organisations - RTPO), upoważnione do wykonywania czynności zatwierdzania ww. personelu NDT.

Ponieważ dyrektywa nie określa metodologii zatwierdzania, forum europejskich jednostek notyfikowanych i RTPO opracowało i uzgodniło dokument w tej sprawie, którego projekt przedłożono do CEN. W wyniku tego postępowania powstał dokument normalizacyjny o statusie raportu technicznego CEN/TR 15589:2007. Dokument został znowelizowany i nowe wydanie powstało w lutym 2014 r. [5]. Dokument ten ma na celu zapewnienie jednolitego podejścia oraz wysokiego poziomu zaufania do zatwierdzania personelu badań nieniszczących przez RTPO, poprzez powszechne przyjęcie kryteriów i realizacji procesu zatwierdzania.

Podstawą decyzji RTPO o zatwierdzeniu personelu badań nieniszczących zgodnie z dyrektywą ciśnieniową powinna być ważna kwalifikacja lub certyfikat kompetencji wydany zgodnie z zasadami jednostki drugiej lub trzeciej strony, wydany w odpowiednim sektorze. Istnieją trzy ścieżki zatwierdzania personelu - A, B i C. Rysunek 2 przedstawia schemat uzyskiwania zatwierdzenia przez RTPO.

A. Certyfikacja przez RTPO. Osoby są certyfikowane zgodnie ze harmonizowaną EN ISO 9712 w odpowiednim sektorze przez jednostkę certyfikującą uznaną także jako RTPO,

B. Certyfikacja przez jednostkę, która nie jest RTPO. Osoby, które są certyfikowane zgodnie z zharmonizowaną EN ISO 9712 w odpowiednim sektorze przez jednostkę certyfikującą, która nie jest RTPO,

C. Przypadki inne niż ścieżki A i B. Osoby kwalifikowane w odpowiednim sektorze z zastosowaniem kryteriów równoważnych tym w zharmonizowanej normie europejskiej EN ISO 9712.

W przypadku C osoba nie posiada certyfikatu wg EN ISO 9712, ale przeszła z zadowalającym wynikiem proces kwalifikowania (np. wg ASNT lub wg procedury pracodawcy)

1 Dyrektywa ciśnieniowa 97/23/WE obecnie obowiązująca do połowy 2016 r.

2 Dyrektywa ciśnieniowa 2014/68/WE obowiązywać będzie od połowy 2016 r. za wyjątkiem art. 13, który obowiązuje od 1 czerwca $2015 \mathrm{r}$. 
i ubiega się o zatwierdzenie. Wtedy RTPO może zatwierdzić taką osobę po upewnieniu się, że spełnia ona wymagania co najmniej normy zharmonizowanej (EN ISO 9712). W tym celu RTPO powinna posiadać system kwalifikacji w formie auditu $\mathrm{w}$ miejscu pracy oraz powołać i autoryzować osobę(-y) z certyfikatem 3.stopnia w metodach i sektorach, w których ma nastąpić zatwierdzenie. Podczas auditu należy sprawdzić czy osoba wnioskująca:

- udokumentowała spełnienie wymagań odnośnie wzroku (ostrość widzenia i rozróżnialność barw),

- ukończyła przed egzaminem odpowiednie szkolenie,

- uzyskała odpowiednią praktykę,

- zdała z wynikiem pozytywnym egzaminy teoretyczne ogólny i specjalistyczny,

- zdała z wynikiem pozytywnym stanowiskowy egzamin praktyczny odpowiedni do badania połączeń nierozłącznych urządzeń ciśnieniowych,
- wykonuje badania połączeń nierozłącznych urządzeń ciśnieniowych bez istotnej przerwy,

- jest zaznajomiona z procedurami / instrukcjami badawczymi.

Osoba autoryzowana powinna także przeprowadzić odpowiedni egzamin praktyczny.

Pozytywny wynik oceny stanowi podstawę do wydania świadectwa zatwierdzenia osoby do wykonywania NDT połączeń nierozłącznych urządzeń ciśnieniowych określoną metodą i w odpowiednim sektorze.

Rysunek 2 przedstawia schematycznie ścieżki zatwierdzania personelu NDT.

\section{Normy}

Wymagane kompetencje personelu wykonującego badania nieniszczące zawarte są w normach wyrobu i w normach z nimi związanych oraz w normach badań.

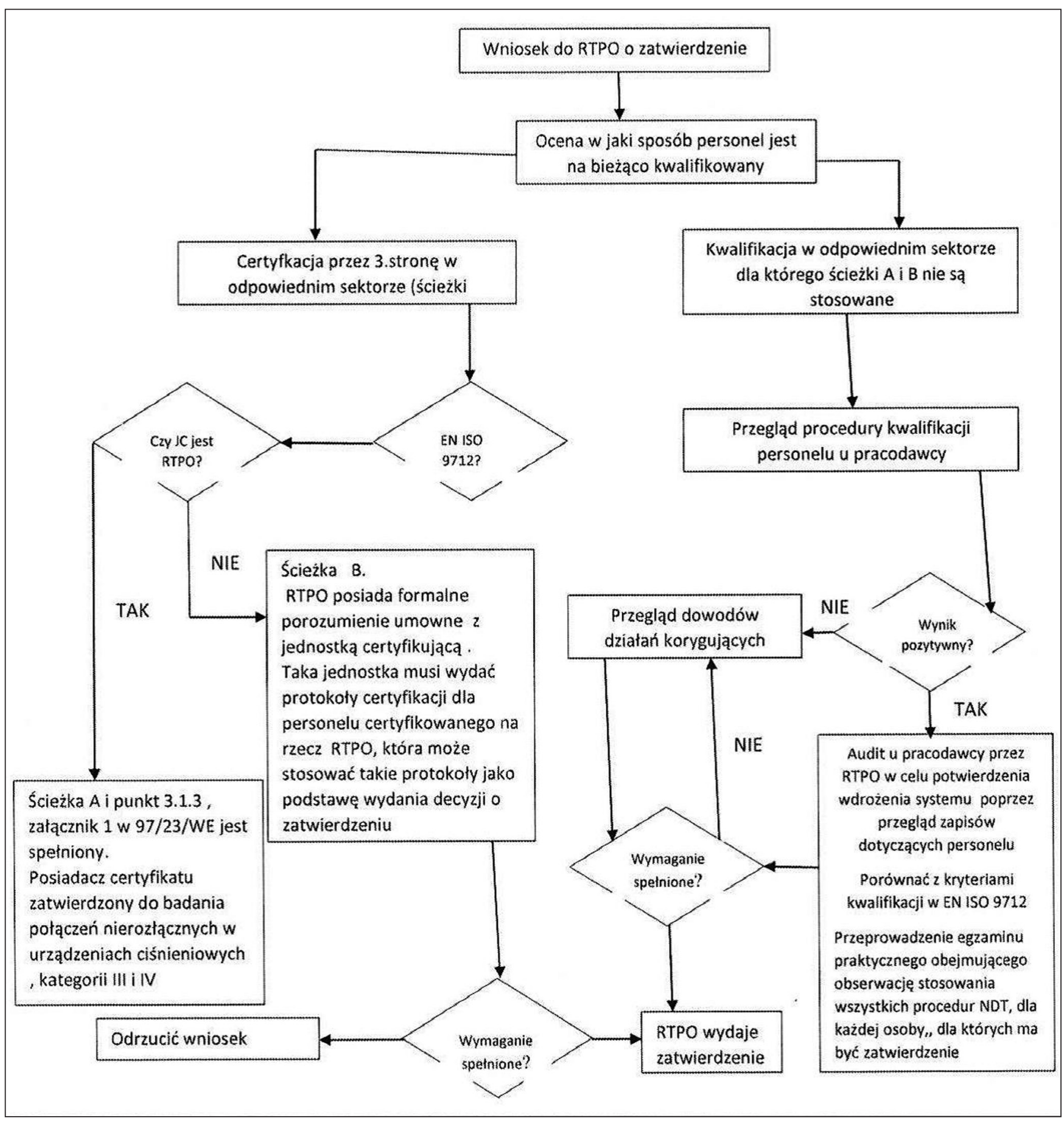

Rys. 2. Schemat uzyskiwania zatwierdzenia przez RTPO

Fig. 2. Scheme of obtaining the approval by RTPO 
Jak odnosić się do tych wymagań?

Jeśli mamy do czynienia z oceną zgodności wyrobu wg PED, a proces oceny odbywa się w oparciu o normy zharmonizowane $z$ tą dyrektywą, stanowiące domniemanie spełnienia tych wymagań, to konieczne jest zidentyfikowanie wymagań dla personelu NDT rozpoczynając od normy zharmonizowanej wyrobu czyli urządzeń ciśnieniowych.

Na przykładzie serii norm PN-EN 13445 dotyczącej nieogrzewanych płomieniem zbiorniki ciśnieniowych omówione zostanie postępowanie zmierzające do określenia wymagań dla personelu NDT.

Część 5 tej normy dotycząca kontroli i badań zawiera wymaganie dotyczące kompetencji osób wykonujących badania nieniszczące połączeń spawanych, które określa, że personel wykonujący takie badania powinien być kwalifikowany i certyfikowany wg PN-EN ISO 9712 za wyjątkiem badań wizualnych, w przypadku których wymagane jest tylko kwalifikowanie. Personel NDT powinien posiadać odpowiednio certyfikaty 1, 2 czy 3 stopnia [6].

PN-EN 13445 - 5 powołuje szereg norm, wśród których jest PN-EN 13445-2 określająca wymagania dla materiałów do budowy zbiorników ciśnieniowych, zaś ta powołuje szereg norm wyrobów metalowych, jak np. blachy, odkuwki itp. W normach tych z kolei znajdujemy powołania norm określające ogólne dla nich wymagania, a te powołują normy badań $[7 \div 10]$.

Rysunek 3 przedstawia przykład kolejnych powołań w przypadku badań penetracyjnych odkuwek swobodnie kutych.

PN-EN 10228-2:2000 określa wymagania dla personelu wykonującego badania penetracyjne odkuwek swobodnie kutych - powinny to być osoby kwalifikowane i certyfikowane zgodnie z PN-EN 473 (norma niedatowana, co oznacza, że należy stosować jej najnowszą edycję, a jest nią EN ISO 9712:2012.

Tak więc zarówno połączenia nierozłączne urządzeń jak i wyroby przeznaczone do ich budowy powinny być badane przez personel NDT kwalifikowany i certyfikowany wg PN-EN ISO 9712:2012.

\section{Stopnie kwalifikacji i odpowiedzialności}

Kompetencje i upoważnienia wg PN-EN ISO 9712

PN-EN ISO 9712 określa kompetencje personelu NDT dla każdego stopnia oraz wskazuje do jakich zadań mogą być upoważnione przez pracodawcę osoby z poszczególnymi stopniami.

\section{1. stopień}

Osoba z 1.stopniem może wykonywać badania pod nadzorem 2 lub 3 stopnia, według pisemnych instrukcji. Pracodawca może upoważnić taką osobę do wszystkich lub niektórych spośród następujących czynności:

- nastawiania aparatury badawczej,

- przeprowadzania badań,

- notowania wyników i klasyfikowania ich wg kryteriów określonych w pisemnej instrukcji badania,

- sporządzenia protokołu z badań.

Personel 1. stopnia nie może posiadać upoważnienia do doboru metody lub techniki badania, ani do interpretowania wyników.

\section{2. stopień}

Personel certyfikowany na 2. stopień może wykonywać badania na podstawie procedur / norm, a pracodawca może go upoważnić do:

- decydowania o wyborze techniki badania w ramach danej metody,

- ustalania ograniczenia metody,

- sporządzania instrukcji dostosowanych do rzeczywistych warunków pracy na podstawie wymagań kodeksów, norm, specyfikacji i procedur,

- nastawiania i sprawdzania ustawień aparatury badawczej,

- przeprowadzania i monitorowania przebiegu badań,

- interpretowania i oceniania rezultatów badań zgodnie z normami, kodeksami, specyfikacjami lub procedurami,

PN-EN 13445-5 Nieogrzewane płomieniem zbiorniki ciśnieniowe

Część 5: Kontrola i badania

PN-EN 13445-2 Nieogrzewane płomieniem zbiorniki ciśnieniowe

Część 2: Materiały

PN-EN 10222-4 Odkuwki stalowe na urządzenia ciśnieniowe

Cz.4: Stale spawalne drobnoziarniste o podwyższonej granicy plastyczności

$\sqrt{ }$

PN-EN 10222-1 Odkuwki stalowe na urządzenia ciśnieniowe.

Ogólne wymagania dotyczące odkuwek swobodnie kutych

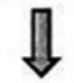

PN-EN 10228-2 Badania nieniszczące odkuwek stalowych - Badanie penetracyjne

Rys. 3. Normy wyrobu - odkuwki swobodnie kute - przykład

Fig. 3. Product standards - forgings - example 
- realizowania czynności jak dla 2. i 1. stopnia oraz nadzorowania personelu 1. i 2. stopnia,

- opracowywania wytycznych dla 1. i 2. stopnia

- sporządzania i podpisywania wyników badań.

\section{3. stopień}

Osoba z 3. stopniem jest kompetentna w zakresie oceniania i interpretowania wyników według norm, kodeksów i specyfikacji. Posiada wiedzę na temat materiałów, technologii wytwarzania dzięki czemu jest zdolna do wyboru metod i technik NDT oraz do ustalania kryteriów akceptacji, jeśli takich nie ma. Posiada również ogólną wiedzę z zakresu innych metod badawczych.

Osobę taką pracodawca może upoważnić do:

- całkowitej odpowiedzialności za laboratorium lub ośrodek egzaminacyjny i personel w nich zatrudniony,

- zatwierdzania instrukcji i procedur,

- interpretacji kodeksów, norm, specyfikacji i procedur,

- wdrażania w laboratorium specjalnych metod, procedur i instrukcji,

- realizacji i nadzorowania wszystkich obowiązków wszystkich stopni,

- opracowywania wytycznych dla 1., 2. i 3.stopnia.

\section{Odpowiedzialność pracodawcy}

PN-EN ISO 9712 adresowana jest do wszystkich stron biorących udział i zainteresowanych w procesie certyfikacji czyli do jednostki certyfikującej, pracodawcy, kandydata i osoby certyfikowanej, oraz określa ich odpowiedzialności.

W niniejszym artykule zwracam uwagę przede wszystkim na odpowiedzialność pracodawcy jako ważny element spełnienia wymagań certyfikacyjnych wstępnych oraz w zakresie utrzymania ważności certyfikacji.

Pracodawca zobowiązany jest do przedstawienia kandydata jednostce certyfikującej i odpowiednio potwierdzić, że przedłożone dane są właściwe i ważne. Są to zwykle akceptowalne przez jednostkę oświadczenia dotyczące wykształcenia, szkolenia i praktyki oraz wzroku. Oświadczenia takie stanowią podstawę do zakwalifikowania kandydata do egzaminu kwalifikacyjnego. Kandydat bezrobotny lub prowadzący własną firmę, przedstawia oświadczenia potwierdzone przez co najmniej jedną niezależną stronę, akceptowalną przez jednostkę certyfikującą.

Pracodawca jest odpowiedzialny za personel certyfikowany w zakresie:

- wystawienia pisemnego upoważnienia do wykonywania odpowiednich czynności spośród tych właściwych dla posiadanego stopnia certyfikacji. Certyfikat jest nieważny bez pisemnego upoważnienia pracodawcy.

- zapewnienia szkoleń stanowiskowych.

Pracodawca odpowiada wobec klienta za jakość badań i jakość wyników badań.

Pracodawca ponadto:

- zapewnia coroczną kontrolę wzroku - kieruje na badanie i finansuje badanie,

- sprawdza i dba o zachowanie ciągłości w wykonywaniu czynności, do których upoważnił osobę certyfikowaną - w każdej metodzie i w każdym sektorze osoba certyfikowana powinna wykonywać czynności bez istotnej przerwy ${ }^{3}$. W przypadku, gdy osoba certyfi- kowana nie wykonuje badań np. w jednym z sektorów z zakresu certyfikacji przez okres dłuższy niż istotna przerwa, certyfikat traci ważność w tym sektorze i nie można uzyskać ponowienia certyfikacji w tym właśnie sektorze,

- zapewnia, że personel posiada ważny certyfikat w zakresie swoich zadań w firmie, która go zatrudnia.

Certyfikacja staje się nieważna:

a. gdy jednostka certyfikująca podejmie taka decyzję, np. w wyniku postępowań niezgodnych z zasadami certyfikacji lub nieprzestrzegania kodeksu etycznego;

b. gdy stwierdzono negatywny wynik badania wzroku;

c. gdy wykonywaniu czynności w metodzie lub sektorze nastąpi istotna przerwa;

d. gdy kandydat nie uzyska odnowienia / recertyfikacji w odpowiednim czasie.

Pracodawca powinien posiadać odpowiednie zapisy dotyczące ważności certyfikacji personelu certyfikowanego.

Norma rekomenduje, aby pracodawca posiadał pisemną procedurę opisującą sposób uzyskiwania i utrzymywania certyfikacji personelu badań nieniszczących oraz aby wszystkie odpowiedzialności zostały opisane w tej procedurze.

\section{Wymagania akredytacyjne \\ dla personelu badań nieniszczących; wytyczne $\mathrm{EA}^{4}$}

Dokument EA-4/15 G:2015 zawiera wytyczne dla jednostek akredytujących laboratoria badań nieniszczących. Został on opublikowany w maju 2015 roku; okres przejściowy wynosi 1 rok. Został on wydany jako wytyczne w odniesieniu do akredytacji laboratoriów badawczych wg EN ISO/IEC 17025 lub EN ISO/IEC 17020 [11].

W wytycznych, w rozdziale 4 , określone zostały wymagania dla personelu badań nieniszczących. Jak w każdej metodzie badawczej, tak w NDT, personel powinien mieć odpowiednie, potwierdzone kompetencje. W przypadku, gdy norma badania, np. specyfikacja klienta, nie stanowi inaczej, personel NDT powinien mieć ważne certyfikaty wydane przez akredytowaną jednostkę certyfikującą.

Osoby odpowiedzialne za badania nieniszczące powinny mieć certyfikaty 3 . stopnia dla każdej z metod NDT stosowanych w laboratorium. W przypadku, gdy laboratorium nie zatrudnia na stałe odpowiedniego personelu, powinno zatrudnić dorywczo osoby o odpowiednich kompetencjach.

Jeśli nie jest dostępna akredytowana jednostka certyfikująca, dopuszcza się certyfikat wydany przez inną jednostkę, lecz powinien on być potwierdzony przez kompetentną stronę.

Do zakresu odpowiedzialności osoby z 3. stopniem w laboratorium należy co najmniej:

- przypisywanie personelu NDT jako kompetentnego do wykonywania badań specjalistycznych;

- zatwierdzanie procedur badawczych NDT i walidacja metod - wg PN-EN ISO 9712 3.stopień jest formalnie organem walidującym procedury badawcze. W przypadku procedur rutynowych wg norm badań wystarczy opracować instrukcję badania zatwierdzoną przez 2. stopień;

- zarządzanie wewnętrznym programem szkoleń specjalistycznych dla personelu NDT przed wydaniem pisemne-

\footnotetext{
${ }^{3}$ Istotna przerwa - nieobecność lub zmiana działalności, która uniemożliwia osobie certyfikowanej pełnienie obowiązków odpowiednich do stopnia w metodzie i sektorze(-ach) określonym(-ych) zakresem certyfikacji, w przypadku gdy okres ciągłej przerwy przekracza jeden rok albo co najmniej dwie przerwy przekroczą łącznie dwa lata

UWAGA Przy obliczaniu przerwy nie są brane pod uwagę ustawowe urlopy lub okresy nieobecności spowodowane chorobą lub szkoleniami, trwające krócej niż trzydzieści dni.

${ }^{4}$ EA - European Accreditation - zrzesza krajowe jednostki akredytujące krajów członkowskich UE w celu wypracowania jednolitych form oceny zgodności z wymaganiami przepisów, standardów europejskich i światowych.
} 
go upoważnienia przez pracodawcę oraz wewnętrznym badaniem biegłości zatrudnionego personelu.

Personel NDT powinien być certyfikowany przez niezależną jednostkę certyfikującą wg PN-EN ISO 9712 lub wg innej, jej równoważnej normy.

W przypadku, kiedy personel jest kwalifikowany wg wewnętrznego programu pracodawcy, należy dowieść, że program szkolenia i certyfikacji jest zgodny z uznanymi systemami zatwierdzonymi przez organy niezależne. Ponadto należy wykazać, że personel kwalifikowany wg takiego systemu ma wykształcenie, wiedzę, szkolenie i doświadczenie w wykrywaniu nieciągłości mogących wystąpić w obiektach badanych na odpowiedzialność pracodawcy.

Jeśli personel badawczy jest odpowiedzialny również za określenie istotności nieciągłości wykrytych podczas badania, wymagana jest wiedza z zakresu materiałów, technologii wytwarzania oraz nieciągłości powstających w procesach ich wytwarzania; ponadto wiedza z zakresu zjawisk degradacji materiału podczas eksploatacji i znaczenia tych nieciągłości dla badanego obiektu i dalszej jego eksploatacji.

Obowiązkiem pracodawcy jest monitorowanie pracowników, bieżące szkolenie i prowadzenie odpowiednich zapisów. Monitorowanie może odbywać się poprzez obserwację pracy w laboratorium i w terenie, aby stwierdzić, czy personel pracuje zgodnie z procedurami i uzgodnieniami z klientem.

Pracodawca osoby certyfikowanej jest odpowiedzialny za wszelkie działania personelu wykonującego badania i za wyniki badań. Dotyczy to również znajomości warunków pracy i bezpieczeństwa podczas wykonywania badań u klienta - w takim przypadku za odpowiednie przeszkolenie również odpowiada pracodawca.

Powyższe wymagania i odpowiedzialności pracodawcy dotyczą w równej mierze pracowników zatrudnionych na stałe, jak i dorywczo.

\title{
Wnioski
}

W badaniach nieniszczących ogromny nacisk kładziony jest na kompetencje personelu, którego odpowiedzialność jest bardzo duża ze względu na bezpieczeństwo eksploatacji urządzeń podlegających badaniom.

Ze względu na coraz większy zasięg wolnego rynku w Europie i na świecie, ważnym było uzyskanie jednolitego światowego standardu, który określałby wymagania dotyczące kwalifikowania i potwierdzania kompetencji personelu NDT. W 2012 r., po wielu latach funkcjonowania EN 473 i ISO 9712 w tym zakresie, udało się dopracować jednej normy PN-EN ISO 9712, którą stosuje cały świat.

Norma PN-EN ISO 9712 bardzo podkreśla rolę i odpowiedzialność pracodawcy osoby wykonującej badania za wszystkie czynności z tego zakresu oraz za wyniki badań. Dlatego istotne jest, aby pracodawcy świadomi tej odpowiedzialności, zatrudniali odpowiedni personel NDT i nadzorowali jego kompetencje poprzez ciągłe szkolenia i badanie biegłości.

Personel laboratoriów wykonujących badania nieniszczące powinien spełniać wymagania określone w PN-EN ISO/ IEC 17025, które w formie wytycznych w EA-4/15 G:2015 zostały rozwinięte z zaleceniem stosowania ich w laboratoriach badań nieniszczących.

Badana nieniszczące wg wymagań zasadniczych dyrektywy ciśnieniowej PED powinien wykonywać personel zatwierdzony przez upoważnioną jednostkę trzeciej strony.

\section{Literatura}

[1] PN-EN 17024:2012 Ocena zgodności - Ogólne wymagania dotyczące jednostek certyfikujących osoby.

[2] PN-EN ISO 9712:2012 Badania nieniszczące - Kwalifikacja i certyfikacja personelu badań nieniszczących.

[3] Dyrektywa 97/23/we Parlamentu Europejskiego i Rady z dnia 29 maja 1997 r. w sprawie zbliżenia ustawodawstw Państw Członkowskich dotyczących urządzeń ciśnieniowych.

[4] Dyrektywa Parlamentu Europejskiego i Rady 2014/68/UE z dnia 15 maja 2014 r. w sprawie harmonizacji ustawodawstw państw członkowskich odnoszących się do udostępniania na rynku urządzeń ciśnieniowych.

[5] CEN/TR 15589 „Non destructive testing - Code of practice for the approval of NDT personnel by recognised third party organisations under the provisions of Directive 97/23/WE (Badania nieniszczące -Praktyka zatwierdzania personelu badań nieniszczących zgodnie z postanowieniami dyrektywy 97/23/WE przez uznane jednostki trzeciej strony).
[6] PN-EN 13445-5 Nieogrzewane płomieniem zbiorniki ciśnieniowe - Część 5: Kontrola i badania.

[7] PN-EN 13445-2 Nieogrzewane płomieniem zbiorniki ciśnieniowe - Część 2: Materiały.

[8] PN-EN 10222-4 Odkuwki stalowe na urządzenia ciśnieniowe - Część 4: Stale spawalne drobnoziarniste o podwyższonej granicy plastyczności.

[9] PN-EN 10222-1 Odkuwki stalowe na urządzenia ciśnieniowe. Ogólne wymagania dotyczące odkuwek swobodnie kutych

[10] PN-EN 10228-2 Badania nieniszczące odkuwek stalowych - Badanie penetracyjne.

[11] EA-4/15 G:2015 Akredytacja w badaniach nieniszczących.

\section{ZAMÓW NEWSLETTER}

\author{
Zapraszamy Państwa do zapisania się na bezpłatny \\ NEWSLETTER Przeglądu Spawalnictwa, \\ w tym celu należy wysłać e-mail z tematem \\ “NEWSLETTER" na adres: redakcja@pspaw.pl
}

